\title{
Comparing the Effect of Seven Isolated Bacillus Thuringiensis against Tuta absoluta Infesting in Laboratory and Field Condition
}

\author{
Sabbour Magda ${ }^{1}$, Maysa E. Moharam ${ }^{2}$ \\ ${ }^{1}$ Pests and Plant Prot., Dept \\ ${ }^{2}$ Microbial Chemistry Department, Genetic Engineering \& Biotechnology Div. . National Research Centre, Cairo Egypt, El-Tahrir St. \\ Dokki, Cairo, Egypt
}

\begin{abstract}
Under laboratory, the effect of the tested bacteria conditions Bacillus thuringiensis strains on the target insect pests $T$. absoluta showed that, the LC50 obtained, 139, 120, 60, 55, 154 and $150 \mathrm{Ug} / \mathrm{ml}$ after treated with B.T IP Dendrolimus, B.t thuringiensis, Bt Sotto 4A/4B, BT IP thurizide, Bt Toloworthi Bt,HD 210 and Bt HD 128, respectively. Under semifield conditions, the LC50 of T. absoluta 159, 140, 70 65, 73184 and $170 \mathrm{Ug} / \mathrm{ml}$ after treated with corresponding pathgens, respectively . under field conditions, the mean number of T. absoluta after treated with, Bt HD 210 and Bt HD 210 treatments which recorded, $44.5 \pm 10.6$ and $452.8 \pm 13.5$ individuals as compared to $99.8 \pm 15.5$ individual in the control after 125 days of the first applications. Also, the lowest number of infestations of T. absoluta recorded 10.4 \pm 10.9 individuals after Bt Toloworthi treatments.
\end{abstract}

Keywords: Tuta absoluta, Bacteria. Bacillus thuringiensis, B.T IP Dendrolimus ,B.t thuringiensis, Bt Sotto 4A/4B, BT IP thurizide ,Bt Toloworthi Bt ,HD 210 and Bt HD 128.

\section{Introductions}

Tomato (Lycopersicone sculentum Mill.) is one of the most important Solanaceous vegetable crops. The tomato plants are currently infested with many serious pests, recently the most destructive ones, Tuta absoluta. Itis one of the most important pests of tomato in Egypt which is posing a serious threat to tomato production. This pest is crossing borders rapidly and devastating tomato production substantially. Caterpillars prefer leaves and stems, but may also occur underneath the crown of the fruit and even inside the fruit itself. The caterpillars attack only green fruit. Most distinctive symptoms are the blotch-shaped mines in the leaves. Inside these mines both the caterpillars. In case of serious infection, leaves die off completely. Mining damage to the plant causes its malformation. Damage to fruit allows e.g. fungal diseases to enter, leading to rotting fruit before or after harvest , (EPPO, 2008. a\&b). Tomato grown in green house and open field. Severely attacked tomato fruits lose their commercial value. 50-100\% losses have been reported on tomato (EPPO,2009 a \&b). Sabbour 2014, used the Biocontrol agent for controlling the Tomato Pinworm Tuta absoluta (Meyrick) (Lepidoptera: Gelechiidae) in Egypt. Sabbour, 2009 control the tomato insect pests by using bacillus thuringiensis and the entomopathogenic fungi. The aim of this work to evaluate of seven isolated bacterial strains of Bacillus thuringiensis against $T$. absoluta under laboratory, greenhouse effect and field. Sabbour and Nayera Solieman 2014,controlled T. absoluta by the fungi. Sabbour and Singer 2014 found that the number of $T$. absoluta significantly decreased after fungi treatments,

\section{Material and Methods}

\subsection{Rearing Insect Pests}

The tomato pinworm were reared on tomato leaves under laboratory conditions $22 \pm 2 \mathrm{C}^{\circ}$ and $\mathrm{RH} 60-70 \%$ T. absoluta used in the trials were obtained from laboratory cultures. The experiments were repeated 4 times. The percentages of mortality were calculated and corrected according to Abbott, 1925, while LC50 was calculated through probit analysis, (Finney, 1964). The experiments were carried out under laboratory conditions $22 \pm 2 \mathrm{o} \mathrm{C}$ and $60-70 \%$ R.H. Twenty individuals of the third larvae of $T$. absoluta were put on them, covered with muslin. Control (untreated) was made by feeding the larvae on untreated leaves(sprayed by water only). The experiments were repeated 4 times. The percentages of mortality determined after seven days. The percentages of mortality were counted and calculated according to Abbott, (1925), while Lc50were calculated through probit analysis Finney, (1964). The experiments were carried under laboratory conditions; $22 \pm 20 \mathrm{C}$ and $60 \pm$ $5 \% \mathrm{RH}$.

\subsection{Microorganisms}

Bacillus thuringiensis B.T Tenebrionis, B.t thuringiensis, Bt Sotto, 4A/4B BT IP thurizide, Bt Toloworthi ,Bt HD 210 and $B t$ HD 128, were used in this study. The bacterial cultures were maintained on nutrient agar slants at $4^{\circ} \mathrm{C}$.

\subsection{Bacterial Culture Media}

The conventional laboratory culture broth, Nutrient broth , was used for culture preparation by mixing $5 \mathrm{~g}$ peptone and $3 \mathrm{~g}$ beef extract/ $1 \mathrm{~L}$ distilled water. $50 \mathrm{ml}$ of sterile medium was inoculated with one loopful of bacterial strain and 


\section{International Journal of Science and Research (IJSR) \\ ISSN (Online): 2319-7064}

Index Copernicus Value (2013): 6.14 | Impact Factor (2014): 5.611

incubated under shaking growth conditions on an orbital rotary shaker $(125 \mathrm{rpm})$ at $30^{\circ} \mathrm{C}$ for $72 \mathrm{~h}$.

\subsection{Effect of the Microbial Control Agents}

Isolated Bacillus thuringiensis (Bt) B.T Tenebrionis , B.t thuringiensis, Bt Sotto, 4A/4B ,BT IP thurizide, Bt Toloworthi, Bt HD 210 and Bt HD 128; were used to test their activities on stored insect pests $T$. absoluta adult beetles. The dead larvae of $B$. incarnatus were collected from the colony.. The Bt strains tested and prepared at concentrations $(500,250,125,63,32$ and $16 \mathrm{ug} / \mathrm{ml})(\mathrm{w} / \mathrm{v})$. The tomato leaves were sprayed by tested concentrations of $\mathrm{Bt}$ and left to dry under laboratory conditions. Control treatment was made by feeding the larvae on untreated leaves. The percentages of mortality were counted and calculated according to 50 Abbott ,1925, while LC50 were calculated through probit analysis according to Finney, 1964. The experiments were carried under laboratory conditions; $26 \pm 20 \mathrm{C}$ and $60-70 \%$ R.H.

\subsection{Semi-field (green house) trials}

Tomato plant Variety Bio-Bride was planted in the green house in 40 plots in each artificial infestation was made by spraying the plant with the bioinsecticides of bacterial strains ; at the concentrations of $(500,250,125,63,32$ and $16 \mathrm{ug} / \mathrm{ml})(\mathrm{w} / \mathrm{v})$ for each. Control samples were sprayed by water only. The plants were examined every two days, the percentage of infestation was calculated until the end of the experiment. Each treatment was replicated 4 times. The percent mortality was counted and corrected according to Abbott, 1925;while Lc50s were calculated through probit analysis after Finney 1964.

\subsection{Field trials}

The experiments were carried out to study the effectiveness of the tested Bacillus thuringiensis, seven strains , B.T IP Dendrolimus , B.t thuringiensis, Bt Sotto 4A/4B, BT IP thurizide ,Bt Toloworthi Bt ,HD 210 and Bt HD 128, against the target insect pests in two different areas. These two areas were: El-Sharkia and EL-Dakahlia. Tomato planted Variety Bio-Bride planted on the first of April in an area of about $1600 \mathrm{~m}^{2}$, and divided into 16 plots of $50 \mathrm{~m} 2$ each. Four plots were assigned for each pathogen, while 4 plots were treated with water and used as the controls. Each bacterial strain were applied at the concentrations of $300 \mathrm{Ug} / \mathrm{ml}$. Treatments were performed in a randomized plot design at sunset. A five-litre sprayer was used to spray on the treatments. Three applications were made at one week intervals, at the commencement of the experiment. Twenty plant samples were randomly collected at certain time intervals from each plot and transferred to the laboratory for examination. The average number of each of the tested pests/ sample/ plot/treatment was calculated 20, 50, 90 and 120 days after the 1st application. The infestations of target insect pests were then estimated in each case. After harvest, the yield of each treatment was weighed as kgs/feddan.

\section{Results and Discussions}

Results show that, under laboratory, the effect of the tested bacteria conditions Bacillus thuringiensis strains on the target insect pests $T$. absoluta showed that, the LC50 obtained, 139, 120, 60, 55, 154 and $150 \mathrm{Ug} / \mathrm{ml}$ after treated with B.T IP Dendrolimus ,B.t thuringiensis, Bt Sotto 4A/4B, BT IP thurizide ,Bt Toloworthi Bt ,HD 210 and Bt HD 128, respectively (Tabe 1). Tabe 2 , show that the LC50 of $T$. absoluta 159, 140, 70 65, 73184 and $170 \mathrm{Ug} / \mathrm{ml}$ after treated with B.T IP Dendrolimus ,B.t thuringiensis, Bt Sotto 4A/4B, BT IP thurizide ,Bt Toloworthi Bt ,HD 210 and Bt HD 128, respectively. Table 3 , show that the mean number of $T$. absoluta under field conditions which showed that the number recorded after $B t$ HD 210 and $B t$ HD 210 treatments which recorded, $44.5 \pm 10.6$ and $452.8 \pm 13.5$ individuals as compared to $99.8 \pm 15.5$ individual in the control after 125 days of the first applications. Also , the lowest number of infestations of $T$. absoluta recorded $10.4 \pm 10.9$ individuals after Bt Toloworthi treatments Table 4 show that the tomato yield significantly increased to $3199 \pm 51.10,3199 \pm 50.00$,

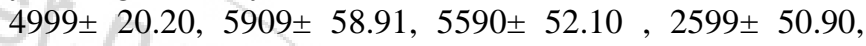
$2409 \pm 20.91 \mathrm{~kg} /$ feddan in the plots treated with, B.T IP Dendrolimus ,B.t thuringiensis, Bt Sotto 4A/4B, BT IP thurizide ,Bt Toloworthi Bt ,HD 210 and Bt HD 128, respectively as compared to $2010 \pm 10.12 \mathrm{~kg} / \mathrm{feddan}$ in $\mathrm{El}$ Sharkia governorate. The corresponding weight of tomato in El- Dakahlia governorate 3901 $\pm 89.30,4094 \pm 71.58,5131 \pm$ $20.10,5199 \pm 54.90,5599 \pm 10.10,2599 \pm 56.80,2459 \pm 20.70$ $\mathrm{kg} /$ feddan as compared to $1801 \pm 81.30 \mathrm{~kg} /$ feddan (Table4).

Figure 1 show the tomato infestation with T. absoluta in ElSharkia governorate which recoded that the infestation were significantly decreased after bacterial treatments especially after BT IP thurizide treatments. Figure 2 in EL-Dakahlia governorate show that the infestations with $T$. absoluta significantly decreased in all bacteria treatments. The same results obtained by Medeiros, et al., 2006, Cabello et al., 2009 , who controlled the pinworm by bioinseticides. Huang et al. 2004) reported that commercial formulates based on this bacterium have been usedfor decades to control insect pests as an alternative to chemicals. Most of the studies that focused on the effect of B. $\mathrm{t}$ on $T$. absoluta have been performed in the region of origin of $T$. absoluta (Giustolin et al. 2001; Theoduloz et al. 2003; Niedmann and Meza-Basso 2006). Giustolin et al. (2001) found that B. $t$ var. kurstaki can cause mortality in all $\mathrm{T}$. absoluta instars and that the use of $\mathrm{Bt}$ has synergistic or additive effects when applied to tomato resistant genotypes. Furthermore, Niedmann and MezaBasso (2006) performed bioassay screens of native $B$. thuringiensis strains from Chile and found that two of them were even more toxic for $\mathrm{T}$. absoluta than the strain isolated from the formulate Dipel (Abbott Laboratories, Chicago, IL, USA).Moreover, Theoduloz et al. (2003) expressed a $B$. thuringiensis toxin in other Bacillus species that naturally colonize the phylloplane of tomato plants, showing that these plant-associated microorganisms could be useful as a delivery system of toxins from B. thuringiensis, which would allow a reduction in pesticide applications. The same results obtained by Medeiros, et al., 2006 Cabello et al., 2009who controlled the pinworm by bioinseticides. Huang et al. 2004) reported that commercial formulates based on this bacterium have been used for decades to control insect pests as an 


\section{International Journal of Science and Research (IJSR) \\ ISSN (Online): 2319-7064}

Index Copernicus Value (2013): 6.14 | Impact Factor (2014): 5.611

alternative to chemicals. Most of the studies that focused on the effect of B. $t$ on $\mathrm{T}$. absoluta have been performed in the region of origin of $T$. absoluta (Giustolin et al. 2001; Theoduloz et al. 2003; Niedmann and Meza-Basso 2006 ). Giustolin et al. (2001) found that B. t var.kurstaki (Btk) can cause mortality in all T. absoluta instars and that the use of $\mathrm{Bt}$ has synergistic or additive effects when applied to tomato resistant genotypes. Furthermore, Niedmann and Meza-Basso (2006) performed bioassay screens of native $B$. thuringiensis strains from Chile and found that two of them were even more toxic for T. absoluta than the strain isolated from the formulate Dipel (Abbott Laboratories, Chicago, IL, USA).Moreover, Theoduloz et al. (2003) expressed a $B$. thuringiensis toxin in other Bacillus species that naturally colonize the phylloplane of tomato plants, showing that these plant-associated microorganisms could be useful as a delivery system of toxins from B. thuringiensis, which would allow a reduction in pesticide applications. Medeiros, et al., 2006; reported that B.t gave a good results against $T$. absoluta. (Goncalves-Gervasio and Vendramin, 2007) recorded that, the entomopathogenic fungus $\mathrm{M}$. anisopliae could be caused female's mortality up to $37.14 \%$ and laboratory studies indicated B. bassiana could cause $68 \%$ larval mortality. Entomopathogenic fungus $M$. anisopliae could be caused female's mortality up to $37.14 \%$. Laboratory studies indicated B. bassiana could cause $68 \%$ larval mortality (Cabello et al., 2009). have shown an important reduction in the number of eggs of T.absoluta, between 92 and $96 \%$, when releasing 8 or 12 first stage nymphs of Nabispseudoferus per plant (Cabello et al., 2009). The same results obtained by Sabbour, 2014, who mentioned, The results showed that under. The same results obtained by Sabbour 2009. Sabbour and Nayera solieman 2014, reported that, The weight of the tomatoes after the harvest scored the highly significance weight reached to $4916 \pm 42.50,4131 \pm 34.33,3123 \pm 41.28, \mathrm{Kg} /$ feddan in the area treated with Bacillus thuringiensis Diple (2X), B.t kurstaki HD-73, and B.t kurstaki HD-234, respectively as compares to $2631 \pm 36.80 \mathrm{Kg} /$ fesddan in the control in ELEsraa farm (Nobaryia) during season 2013. Sabbour and singer 2014 found that, The LC50 of M. anisopliae var. frigidum 156X104 and 168 X104 spores/ml under laboratory and greenhouse effect, respectively. The corresponding LC50of M. flavoviride var. minus were 169 $\mathrm{X} 104$ and $172 \mathrm{X} 104$ spores $/ \mathrm{ml}$. The highest yield obtained

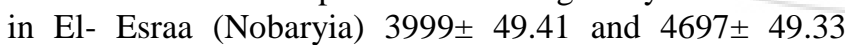
Tons/kg in El-Kassaseen (Ismailia) after M. anisopliae var. frigidum treatments the yield loss ranged between 7 and 72 $\%$ in the two regions. The infestations with Tuta absoluta significantly decreased in plots treated with $M$. anisopliae var. frigidum as compared to the control plots. The same findings obtained by Sabbour,n2009 and 2014.

\section{Acknowledgment}

This research was supported by PROJECT TITLED, BIOLOGICAL CONTROL OF SOME GREENHOUSE TOMATO INSECT PESTS.
Table 1: Effect of the entomopathogenic Bacteria against $T$. absolutas larvae under laboratory conditions

\begin{tabular}{|c|c|c|c|c|}
\hline Pathogen B.t & $L C_{50 \mathrm{Ug} / \mathrm{ml}}$ & Slope & Variance & $\begin{array}{c}95 \% \text { confidence } \\
\text { limits }\end{array}$ \\
\hline B.T Tenebrionis & 139 & 0.1 & 1.01 & $99-170$ \\
\hline B.t thuringiensis & 120 & 0.2 & 1.00 & $89-142$ \\
\hline Bt Sotto 4A/4B & 60 & 0.1 & 1.03 & $30-99$ \\
\hline BT IP thurizide & 55 & 0.4 & 0.1 & $25-98$ \\
\hline Bt Toloworthi & 63 & 0.5 & 1.2 & $29-88$ \\
\hline Bt HD 210 & 154 & 0.1 & 1.04 & $96-169$ \\
\hline Bt HD 128 & 150 & 0.6 & 1.01 & $124-159$ \\
\hline
\end{tabular}

Table 2: Effect of the entomopathogenic Bacteria against $T$. absoluta larvae under semifield conditions

\begin{tabular}{|c|c|c|c|c|}
\hline Pathogen B.t & $\begin{array}{c}\mathrm{LC}_{50} \\
\mathrm{Ug} / \mathrm{ml}\end{array}$ & Slope & Variance & $\begin{array}{c}95 \% \text { confidence } \\
\text { limits }\end{array}$ \\
\hline B.T Tenebrionis & 159 & 0.1 & 1.01 & $99-180$ \\
\hline B.t thuringiensis & 140 & 0.1 & 1.00 & $99-172$ \\
\hline Bt Sotto 4A/4B & 70 & 0.1 & 1.3 & $50-99$ \\
\hline BT IP thurizide & 65 & 0.2 & 0.1 & $55-108$ \\
\hline Bt Toloworthi & 73 & 0.1 & 1.2 & $49-98$ \\
\hline Bt HD 210 & 184 & 0.1 & 1.2 & $90-169$ \\
\hline Bt HD 128 & 170 & 0.1 & 1.1 & $121-199$ \\
\hline
\end{tabular}

Table 3: The effect of the different bacterial treatments against T. absoluta under field conditions

\begin{tabular}{|l|c|c|c|r|}
\hline \multirow{2}{*}{ Treatments } & \multicolumn{4}{c|}{ Mean number of infestation \pm SE after } \\
& $15 \mathrm{D}$ & 30 D & 55 D & $125 \mathrm{D}$ \\
\hline B.T Tenebrionis & $19.15 \pm 12.7$ & $25.7 \pm 12.3$ & $27.1 \pm 11.5$ & $32.4 \pm 11.1$ \\
\hline B.t thuringiensis & $18.5 \pm 10.6$ & $18.5 \pm 17.5$ & $22.5 \pm 15.6$ & $28.5 \pm 14.4$ \\
\hline Bt Sotto 4A/4B & $12.8 \pm 10.5$ & $12.8 \pm 10.5$ & $9.7 \pm 11.8$ & $12.8 \pm 10.5$ \\
\hline BT IP thurizide & $9.8 \pm 9.9$ & $19.6 \pm 1.9$ & $20.8 \pm 10.5$ & $22.8 \pm 10.1$ \\
\hline Bt Toloworthi & $2.11 \pm 11.2$ & $5.7 \pm 12.5$ & $5.9 \pm 12.1$ & $10.4 \pm 10.9$ \\
\hline Bt HD 210 & $28.5 \pm 16.6$ & $28.8 \pm 19.6$ & $39.5 \pm 11.0$ & $44.5 \pm 10.6$ \\
\hline Bt HD 128 & $22.8 \pm 17.5$ & $32.8 \pm 10.5$ & $49.7 \pm 11.8$ & $452.8 \pm 13.5$ \\
\hline Control & $29.8 \pm 9.2$ & $49.8 \pm 9.9$ & $67.8 \pm 14.5$ & $99.8 \pm 15.5$ \\
\hline F value & 28.1 & & & \\
Lsd5\%= & 12.1 & & & \\
\hline
\end{tabular}

Table 4: Weight of harvested tomato fruits after bacterial treatment against target insect pests .

\begin{tabular}{|c|c|c|}
\hline \multirow{2}{*}{ Treatment } & \multicolumn{2}{|c|}{ Tomato Weight of yield in two governorates } \\
\cline { 2 - 3 } & El- Sharkia governorate & EL-Dakahlia governorate \\
\cline { 2 - 3 } & $\mathrm{Kg} /$ Feddan & Kg/Feddan \\
\hline B.T Tenebrionis & $3199 \pm 51.10$ & $3901 \pm 89.30$ \\
\hline B.t thuringiensis & $3199 \pm 50.00$ & $4094 \pm 71.58$ \\
\hline Bt Sotto 4A/4B & $4999 \pm 20.20$ & $5131 \pm 20.10$ \\
\hline BT IP thurizide & $5909 \pm 58.91$ & $5199 \pm 54.90$ \\
\hline Bt Toloworthi & $5590 \pm 52.10$ & $5599 \pm 10.10$ \\
\hline Bt HD 210 & $2599 \pm 50.90$ & $2599 \pm 56.80$ \\
\hline Bt HD 128 & $2409 \pm 20.91$ & $2459 \pm 20.70$ \\
\hline Control & $2010 \pm 10.12$ & $1801 \pm 81.30$ \\
\hline F-value & 31.10 & 35.1 \\
\hline LSD 5\% & 80 & 81 \\
\hline
\end{tabular}




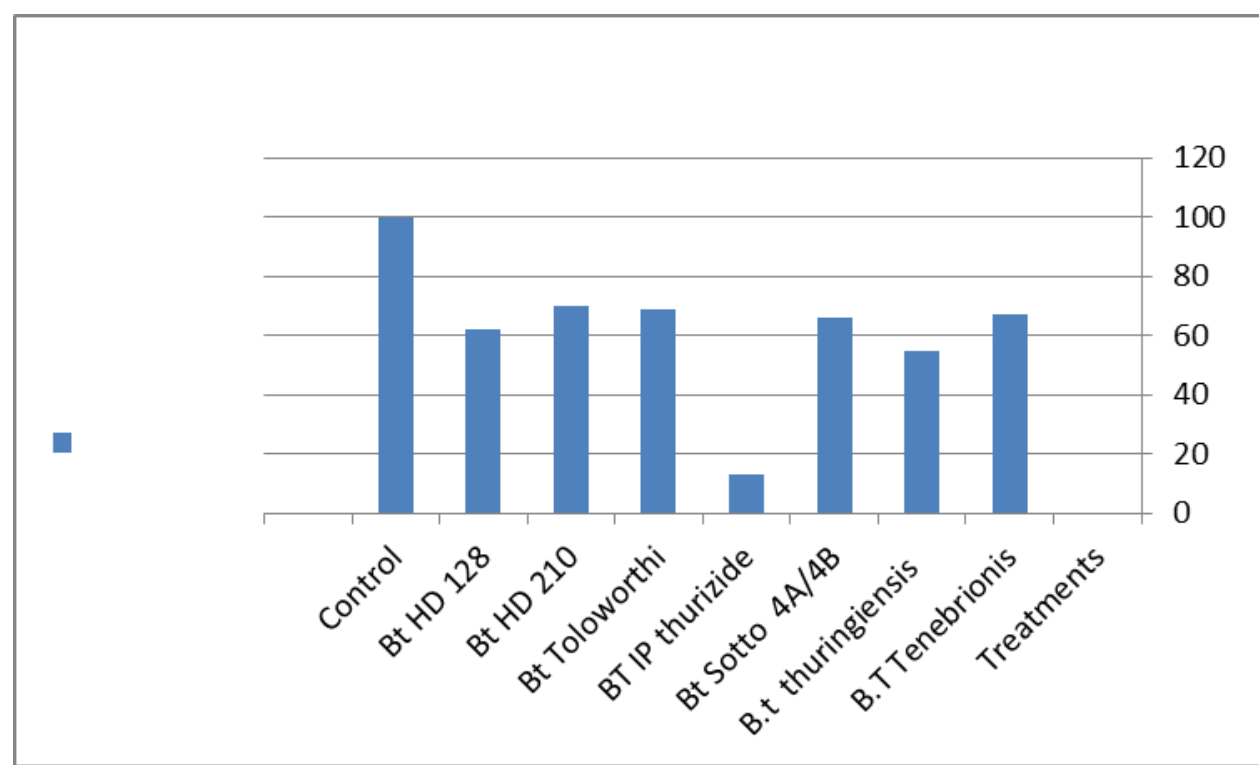

Figure 1: Effect of seven bacterial strains on the infestations of $T$. absoluta in El- Sharkia governorate under field conditions.

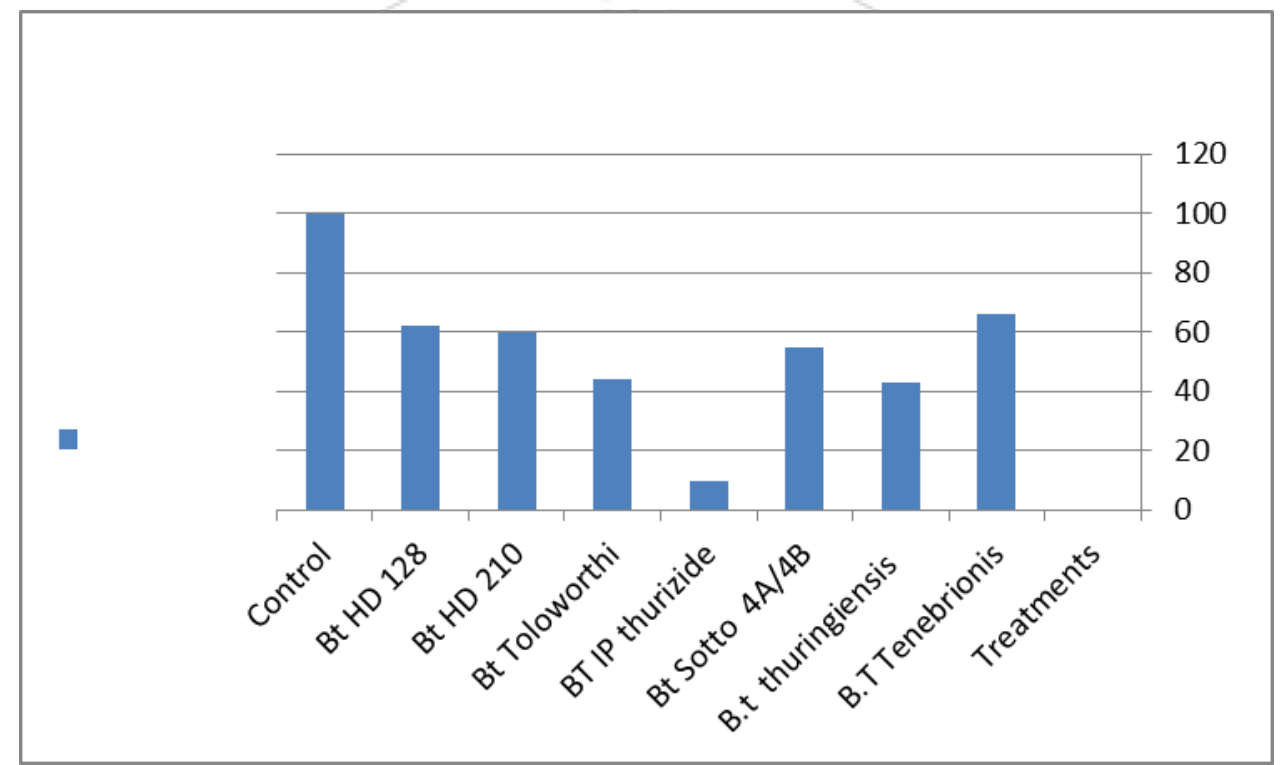

Figure 2: Effect of seven bacterial strains on the infestations of T. absoluta in El- Dakahlia governorate under field conditions

\section{References}

[1] Abbott, W.S., 1925. A method of computing the effectiveness of an insecticides. J. Econ. Ent., 18: 265267.

[2] Cabello, T., J.R. Gallego, E. Vila, A. Soler, M. Pino, del., A. Carnero, E. Hernández-Suárez and A. Polaszek, 2009. Biological control of the South American Tomato Pinworm, Tuta absoluta (Lep.: Gelechiidae), with releases of Trichogrammaachaeae (Hym.:Trichogrammatidae) on tomato greenhouse of Spain. Published in http://www.tutacontrol.com/ accessed 25 of SeptemberCIP. (1996) Major Potato Diseases, Insects, and Nematodes , 3rd edn. Centro Internacionalde la Papa, Lima (PE).

[3] Finney, D.J., 1964. Probit analysis. 2nd Ed., Cambridge. Univ. Press. England. 318 PP.

[4] EPPO, 2008a.First record of Tuta absoluta in Algeria.EPPO reporting service 2008/135.
[5] EPPO, 2008b.First record of Tuta absoluta in Morocco.EPPO reporting service 008/174.EPPO.

[6] EPPO, 2009a.First report of Tuta absoluta in Tunisia.EPPO reporting service 2009/042.

[7] EPPO, 2009b. Tuta absoluta reported for first time from Lazio region Italy. EPPO reporting

[8] service2009/106EPPO.

[9] Giustolin, T.A., J.D. Vendramim, S.B. Alves, S.A. Vieira, R.M. Pereira, 2001. Susceptibility of Tuta absoluta(Meyrick) (Lep., Gelechiidae) reared on two species of Lycopersicon to Bacillus thuringiensis var. kurstaki. J ApplEntomol., 125: 551-556.

[10] Goncalves-Gervasio, R., de C.R. and J.D. Vendramim, 2007.Ciencia e Agrotecnologia, 31(1): 28-34. http://www.tuta absoluta.com/tuta-absoluta)

[11] Medeiros, N.A., D.T. Burnette, P. Forscher, 2006. Myosin II functions in actin-bundle turnover in neuronal growth cones. Nature cell biology, 8: 216-226.

[12] Niedmann, L.L., L. Meza-Basso, 2006. Evaluación de cepasnativas de Bacillus thuringiensis 


\section{International Journal of Science and Research (IJSR) \\ ISSN (Online): 2319-7064}

Index Copernicus Value (2013): 6.14 | Impact Factor (2014): 5.611

comounaalternativa de manejointegrado de la polilla del tomate (Tuta absoluta Meyrick; Lepidoptera: Gelechiidae)en Chile. AgricTe'c, 66: 235-246.

[13] Sabbour, M.M. 2009. Evaluation of two entomopathogenic fungi against some insect pests infesting tomato crops in Egypt, IOBC/wprs Bulletin, Vol. 49: 273-278

[14] Sabbour M.M.2014. Biocontrol of the Tomato Pinworm Tuta absoluta (Meyrick) (Lepidoptera: Gelechiidae) in Egypt. Middle East Journal of Agriculture Research, 3(3): 499-503.

[15] Sabbour, M.M and Nayera, Y. Soliman, 2014,.Evaluations of three Bacillus thuringiensis against Tuta absoluta (Meyrick) (Lepidoptera: Gelechiidae) in Egypt.Volume 3 Issue 8, August 2014. 2319-7064

[16] Sabbour M.M. and Singer, S.M.2014. Evaluations of Two Metarhizium varieties against Tuta absoluta (Meyrick) (Lepidoptera: Gelechiidae) in Egypt. International Journal of Science and Research (IJSR) ISSN (Online): 2319-7064.

[17] Theoduloz, C., A. Vega, M. Salazar, E. Gonza'lez, L. Meza-Basso, 2003. Expression of a Bacillus thuringiensis d-endotoxin cry1Ab gene in Bacillus subtilis and Bacillus licheniformis strains that naturally colonize the phylloplane of tomato plants ( , Mills). J ApplLy copersicone sculentum, Microbiol., 94: 375381. 